\title{
Stress Factors on Pharmacy Technician Personal Satisfaction in Saudi Arabia
}

Yousef Ahmed Alomi* (iD), The Former General Manager of General Administration of Pharmaceutical Care, Former Head National Clinical Pharmacy and Pharmacy Practice, Former Head, Pharmacy R\&D Administration, Ministry of Health, Riyadh, SAUDI ARABIA

Faiz A. Bahadig Rph, Informatics Pharmacist, Pharmaceutical Care Department, King Abdul-Aziz Medical, City-WR-Jeddah, Ministry of National Guard, SAUDI ARABIA.

Budoor Emad Aloumi, Pharmacist, Pharmaceutical Care Services, Ministry of National Guard - Health Affairs. KAMC Central Region, SAUDI ARABIA.

Bayan Ibrahim Alghuraybi, Pharmacy Services, Prince Sultan Military Medical City, Riyadh, SAUDI ARABIA.

Reem Saad Alsubaie, Pharmacy Services, Prince Sultan Military Medical City, Riyadh, SAUDI ARABIA.

\section{Correspondence:}

Yousef Ahmed Alomi, (Bsc. Pharm, MSc. Clin Pharm, BCPS, BCNSP, DiBA, CDE) The Former General Manager of General Administration of Pharmaceutical Care, Former Head, National Clinical Pharmacy and Pharmacy Practice, Former Head, Pharmacy R\&D Administration, Ministry of Health, Riyadh, SAUDI ARABIA.

Phone no: +966 504417712

E-mail:yalomi@gmail.com

Received: 17-03-2019;

Accepted: 22-05-2019

Copyright: ๑ the author(s),publisher and licensee Pharmacology, Toxicology and Biomedical Reports. This is an open-access article distributed under the terms of the Creative Commons Attribution NonCommercial License, which permits unrestricted non-commercial use, distribution, and reproduction in any medium, provided the original work is properly cited.

This is an open access article distributed under the terms of the Creative Commons Attribution-NonCommercial-ShareAlike 4.0 License

Access this article online

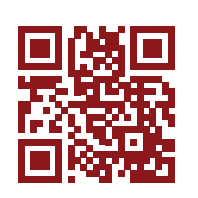

www.ptbreports.org

DOI:

10.5530/PTB.2019.5.25

\begin{abstract}
Purpose: To explore the Stress factors on pharmacy technician personal satisfaction in Saudi Arabia. Methods: It is a 4-months cross-section survey of the stress factors impact of pharmacy technician job satisfaction in Saudi Arabia. The study consisted of 35 questions divided into two-part demographic information and the second part consisted of three parts. Part one was about stress-related factors of pharmacy job. Part two included the questions about pharmacy services units of pharmacy job. Part three questions about communication and relationships factors of pharmacy technician job and overall job satisfaction. The questionnaire was made as an electronic format and it was analyzed through survey monkey system about part one that was about stress-related factors of pharmacy technician job. Results: The total responders were 96 . The gender distribution $83(86.46 \%)$ were males and 13 $(13.54 \%)$ were females. The majority of them $86(89.58 \%)$ were in age group (20-39 years). The average pharmacy technician satisfaction score of pharmacy management policies factors was (3.61), personal pharmacy time was (3.14) and salary and benefits were (2.51). The average score of pharmacy stress factors were (4.03) and the overall job satisfaction was (3.62). The most pharmacy technician motivation factors found were the financial reward and salary advancement was $84(89.36 \%)$ and the flexibility in work scheduling was $63(67.02 \%)$ followed by the Funds to support additional education and training $61(64.89 \%)$ and the time needed for education and training was $61(64.89 \%)$. Conclusion: There are high job stress factors with inadequate pharmacy salary affected negatively pharmacy technician satisfaction in the pharmacy practice. Those factors very essential related motivation factors on pharmacy technician at healthcare institution in the Kingdom of Saudi Arabia.

Keywords: Stress, Factors, Job, Satisfaction, pharmacy technician, personal, Saudi Arabia.
\end{abstract}

\section{INTRODUCTION}

The pharmacy technicians is a significant part of pharmacy staff and healthcare professionals at healthcare institutions. ${ }^{1}$ They need education and training to fulfill the job requirements. ${ }^{2}$ The general administration of pharmaceuticals during pharmacy strategic plan founded on a job training program for new Pharmacy technicians joining hospitals at the Ministry of Health in the Kingdom of Saudi Arabia. ${ }^{2}$ The program aimed to improve pharmacy technician's skills and prepare the new employees to start their jobs at the hospitals. Besides, the Pharmacy administration released local or international scholarship for all pharmacy technicians to complete their education to be pharmacists or gaining a master or Doctor of Philosophy in different pharmacy specialties. The education and training program were one of the significant aspects of motivation factor and improved job satisfaction. Several studies explore the stress job factors with employee satisfaction for pharmacist..$^{3-9}$ Few investigations have been done about pharmacy technicians. ${ }^{10-13}$ The authors based on their best knowledge, there is no evidence of stress factors with pharmacy technicians job satisfaction in the Kingdom of Saudi Arabia or Gulf and Middle East countries. The goal of the study was to explore stress factors affecting pharmacy technician's job satisfaction in Saudi Arabia.

\section{METHODS}

It is a 4 months cross-section survey of the stress factors impacting pharmacy technician job satisfaction in Saudi Arabia. The study consisted of 35 questions divided into two-part demographic information and the second part consisted of three parts. Part one was about stress-related factors of pharmacy job. It included pharmacy management policies, pharmacy stress factors, pharmacy personal time, salary and benefits, pharmacy motivation factors. Part two included the questions about pharmacy services units of pharmacy job. It included pharmacy management structure, dispensing and patient education, clinical pharmacy services, pharmacy technology, pharmacy store and overall job satisfaction. Part three questions were about communication and relationships factors of pharmacy technician job. It included pharmacy supervisors, relationship with coworkers and pharmacist interaction with other healthcare providers, customer interaction and overall job satisfaction. The 5-point Likert response scale system closed ended questions were used. Several factors were involved in the analysis of pharmacy technician's job satisfaction (gender, age, social status, experiences current position, salary). The questionnaire was made as an electronic format and it was analyzed through survey monkey system about part one that was about stress-related factors of pharmacy technician job. 


\section{RESULTS}

The total responders were 96 . Of those $96(100 \%)$ was Saudi and $0(0 \%)$ was non-Saudi. The gender distribution $83(86.46 \%)$ were males and 13 (13.54\%) were females. The majority of them $86(89.58 \%)$ were in age group (20-39 years). The most of pharmacy technicians were married 67 (74.44\%) while $23(25.56 \%)$ were singles (Table 1$)$. In the age group (3039 years) more male gender than age (20-30 years) with significant differences $(p<0.05)$. While in age group (20-30 years) more female gender than the male with significant differences $(p<0.05)$. In the age group (3039 years) more marriage than single status (20-30 years) with significant differences $(p<0.05)$. While in age group $(20-30$ years) more single than marriage status with significant differences $(p<0.05)$.

Most of the pharmacy technicians worked at outpatient pharmacy 50 (59.52\%) than inpatient pharmacy 24 (28.57\%). In all age group categories, there are no significant differences between all categories at current pharmacy works $(p>0.5)$. Most of the responders spent less than three were $28(29.17 \%)$ three years, followed by six to ten years $26(27.08 \%)$ and three to five years $24(25.00 \%)$ and worked in the current position. In the age group (30-39 years) more total years of experience ( $p>6$ years) in the current position than age (20-30 years) with significant differences $(p<0.05)$. While in age group (20-30 years) more total years of experience ( $<3$ years) than age group (30-39 years) with significant differences $(p<0.05)$.

While most of the responders receive 7,000-9,000 SR monthly salary 45 (47.87\%) and 10,000-12,000 SR monthly salary 32 (34.04\%) (Table $2)$. In the age group (30-39 years) more salary (10,000 and above SR)

Table 1: Demographic social information.

\begin{tabular}{|c|c|c|}
\hline Nationality & Response Count & Response Percent \\
\hline Saudi & 95 & $100.00 \%$ \\
\hline Non-Saudi & 0 & $0.00 \%$ \\
\hline Answered question & 95 & \\
\hline Skipped question & 1 & \\
\hline Gender & Response Count & Response Percent \\
\hline Male & 83 & $86.46 \%$ \\
\hline Female & 13 & $13.54 \%$ \\
\hline Answered question & 96 & \\
\hline Skipped question & 0 & \\
\hline Age & Response Count & Response Percent \\
\hline$<19$ & 0 & $0.00 \%$ \\
\hline $20-29$ & 36 & $37.50 \%$ \\
\hline $30-39$ & 50 & $52.08 \%$ \\
\hline $40-49$ & 10 & $10.42 \%$ \\
\hline $50-59$ & 0 & $0.00 \%$ \\
\hline$>60$ & 0 & $0.00 \%$ \\
\hline Answered question & 96 & \\
\hline Skipped question & 0 & \\
\hline Marital status & Response Count & Response Percent \\
\hline Single & 23 & $25.56 \%$ \\
\hline Married & 67 & $74.44 \%$ \\
\hline Other (please specify) & 0 & $0.00 \%$ \\
\hline Answered question & 90 & \\
\hline Skipped question & 6 & \\
\hline
\end{tabular}

than age $(20-30$ years) with significant differences $(p<0.05)$. While in age (20-30 years) more salary (7,000-9,000 SR) than age (30-39 years) with significant differences $(p<0.05)$. In salary income $(10,000-12,000$ SR) more marriage than salary income (7,000-9,000 SR) with significant differences $(p<0.05)$. While in the salary income $(7,000-9,000 \mathrm{SR})$ more singular than salary income (10,000-12,000 SR) with significant differences $(p<0.05)$. In salary income $(10,000-12,000 \mathrm{SR})$ more working at the primary care center and continue to stay in the Pharmacy field than salary income $(7,000-9,000 \mathrm{SR})$ with significant differences $(p<0.05)$.

The most of responders worked at Ministry of health 48 (50\%) followed by $\mathrm{MOH}$ government Hospital 24 (25.00\%) and private Hospital $16(16.67 \%)$. In the age group (30-39 years) more working at $\mathrm{MOH}$ than MOH hospitals (20-30 years) with significant differences $(p<0.05)$. While in age (20-30 years) more $\mathrm{MOH}$ hospitals than $\mathrm{MOH}$ with significant differences $(\mathrm{p}<0.05)$. The responders worked at $(<50$ beds) hospitals 14 (20.00\%) followed by (100-199 beds) 13 (18.57\%) and (200-299 beds) hospitals 11 (15.71\%) and the most hospitals accredited by Saudi Commission for Health Specialties 44 (57.14\%) followed by Saudi Central Board for Accreditation of Healthcare Institutions (CBAHI) 24 (31.17\%) and Joint commission of hospital accreditations USA 9 (11.69\%) (Table $3)$. In all age categories, there are no significant differences between all categories at hospital bed capacity $(p>0.5)$. The finding showed for gender factor there are no significant differences between male or female and social status (married or single), experiences of current position and most of salary income factors for all communication parameters $(p>0.5)$. The average pharmacy technician satisfaction score of pharmacy management policies factors was (3.61), In the age group (30-39 years) more strongly agree in free how to work, have excessive work, had a shortage of staff than age $(20-30$ years $)$ with significant differences $(p<0.05)$. While in age group (20-30 years) more disagree in the flexible schedule than age group (30-39 years) in the flexible schedule or working in the weekend with significant differences $(p<0.05)$. Otherwise, in all age categories, there are no significant differences between all categories at pharmacy management policy satisfaction elements $(p>0.5)$. In the personal pharmacy time was (3.14), In the age group (30-39 years) more strongly disagree in had time for medical education, more disagree in had time for rest, more agree with had effective in changing therapy than age group (20-30 years) with significant differences $(p<0.05)$. In the salary and benefits were (2.51), in all age categories, there are no significant differences between all categories with salary and benefits satisfaction elements $(p>0.5)$ (Table 4$)$. The average score of pharmacy stress factors were (4.03), in the age group (30-39 years) more agree in high workload negatively affected the mental and emotional health, strongly agree in high workload negatively affected qualify of pharmacy work than age group (20-30 years) with significant differences $(p<0.05)$. And the overall job satisfaction was (3.62), in all age categories, there are no significant differences between all categories at overall job satisfaction elements $(p>0.5)$ (Table 5). Most of the pharmacy technician motivation factors found were the financial reward and salary advancement was 84 $(89.36 \%)$ and the flexibility in work scheduling was $63(67.02 \%)$ followed by the funds to support additional education and training $61(64.89 \%)$ and the time needed for education and training was 61 (64.89\%) (Table 6). The finding showed for gender factor there are no significant differences between male or female and social status married or single, experiences of current position and most of salary income for all stress related elements $(p>0.5)$. In all factors including all age group categories, gender, age, social status, experiences current position, salary, there are no significant differences between all factors and the method of motivations elements $(p>0.5)$. 
Table 2: Demographic responder qualifications information.

\begin{tabular}{|c|c|c|}
\hline The practice area & Response Count & $\begin{array}{c}\text { Response } \\
\text { Percent }\end{array}$ \\
\hline Inpatient Pharmacy & 24 & $28.57 \%$ \\
\hline Outpatient Pharmacy & 50 & $59.52 \%$ \\
\hline Narcotics & 1 & $1.19 \%$ \\
\hline Extemporaneous Preparation & 1 & $1.19 \%$ \\
\hline Inventory Control & 0 & $0.00 \%$ \\
\hline Emergency pharmacy & 4 & $4.76 \%$ \\
\hline Drug Information & 0 & $0.00 \%$ \\
\hline All (All previous sections) & 2 & $2.38 \%$ \\
\hline PCC pharmacy & 2 & $2.38 \%$ \\
\hline Pharmacy licensees & 1 & $1.19 \%$ \\
\hline Answered question & 84 & \\
\hline Skipped question & 12 & \\
\hline $\begin{array}{l}\text { Total years you worked in current } \\
\text { position }\end{array}$ & Response Count & $\begin{array}{c}\text { Response } \\
\text { Percent }\end{array}$ \\
\hline$<3$ & 28 & $29.17 \%$ \\
\hline $3-5$ & 24 & $25.00 \%$ \\
\hline 6-10 & 26 & $27.08 \%$ \\
\hline $11-15$ & 6 & $6.25 \%$ \\
\hline$>15$ & 12 & $12.50 \%$ \\
\hline Answered question & 96 & \\
\hline Skipped question & 0 & \\
\hline Monthly income & Response Count & $\begin{array}{c}\text { Response } \\
\text { Percent }\end{array}$ \\
\hline$<6.000$ & 2 & $2.13 \%$ \\
\hline $7.000-9.000$ & 45 & $47.87 \%$ \\
\hline $10.000-12.000$ & 32 & $34.04 \%$ \\
\hline $14,000-16,000$ & 9 & $9.57 \%$ \\
\hline $18,000-20,000$ & 5 & $5.32 \%$ \\
\hline$>25.000$ & 1 & $1.06 \%$ \\
\hline Answered question & 94 & \\
\hline Skipped question & 2 & \\
\hline
\end{tabular}

\section{DISCUSSION}

Pharmacy technician human resources was part of the pharmacy strategic plan. ${ }^{14,15}$ The key performance indicators (KPI) were founded with the plan to monitor the implantation of the pharmacy services at all healthcare institution at Ministry of Health in the Kingdom of Saudi Arabia. One of the effective KPI was pharmacy job satisfaction including pharmacy technicians. In the current study part of the plan implementation of the KPI. This paper reports on the levels of job satisfaction among pharmacy technician in the Kingdom of Saudi Arabia, as well as the likely causes of stress and job pressure and low job gratification in this group. The findings of the study showed the pharmacy management policies are not acceptable. That is related to high workload with inadequate staff and the environmental working conditions is not appropriate, similar finding was observed with previous study with pharmacists. ${ }^{7}$ The working environment has direct impact on the working
Table 3: Demographic hospital information.

\begin{tabular}{|c|c|c|}
\hline Sector of work & Response Count & $\begin{array}{c}\text { Response } \\
\text { Percent }\end{array}$ \\
\hline Ministry of Health & 48 & $50.00 \%$ \\
\hline $\begin{array}{l}\text { General Medical Directorate in } \\
\text { Region }\end{array}$ & 2 & $2.08 \%$ \\
\hline MOH government Hospital & 24 & $25.00 \%$ \\
\hline Non- MOH government Hospital & 5 & $5.21 \%$ \\
\hline MOH-Primary Care Center & 1 & $1.04 \%$ \\
\hline Private Hospital & 16 & $16.67 \%$ \\
\hline Community pharmacy & 0 & $0.00 \%$ \\
\hline Other (please specify) & 0 & $0.00 \%$ \\
\hline Answered question & 96 & \\
\hline Skipped question & 0 & \\
\hline Number of beds at your hospital & Response Count & $\begin{array}{c}\text { Response } \\
\text { Percent }\end{array}$ \\
\hline$<50$ & 14 & $20.00 \%$ \\
\hline $50-99$ & 6 & $8.57 \%$ \\
\hline 100-199 & 13 & $18.57 \%$ \\
\hline 200-299 & 11 & $15.71 \%$ \\
\hline 300-399 & 9 & $12.86 \%$ \\
\hline $400-499$ & 5 & $7.14 \%$ \\
\hline $500-599$ & 4 & $5.71 \%$ \\
\hline$=$ or $>600$ & 2 & $2.86 \%$ \\
\hline Medical City & 6 & $8.57 \%$ \\
\hline Answered question & 70 & \\
\hline Skipped question & 26 & \\
\hline The hospital accreditation & Response Count & $\begin{array}{c}\text { Response } \\
\text { Percent }\end{array}$ \\
\hline CBAHI & 24 & $31.17 \%$ \\
\hline Joint Commotion USA & 9 & $11.69 \%$ \\
\hline Canada & 0 & $0.00 \%$ \\
\hline $\begin{array}{l}\text { Saudi commission of health } \\
\text { accreditation }\end{array}$ & 44 & $57.14 \%$ \\
\hline Answered question & 77 & \\
\hline Skipped question & 19 & \\
\hline
\end{tabular}

staff. The facilities arrangement and the smooth workflow in the working environment preferred among working staff especially in heavy workload stations, that will give the chance for the working staff to be more vigilant which is required when we deal with medications. Also working in well-designed environment meet all the demands according to the updated recommendation and standards of the pharmacy practice which will increase the proper communication between the working staff and patients. Those factors may affect negatively on pharmacy technicians job satisfaction. The pharmacy technician's time is not adequate that is related to the unavailable time to medical education or take a break during duty. The pharmacy technicians satisfaction on the salary was poor, which the lowest factor affect the pharmacy technicians job satisfaction similar to previous studies. ${ }^{10}$ That is related to the payment is to meet the heavy workload in practice, the pharmacy technicians not satisfied with their salary and sometimes the salary is not equal to other organizations. The pharmacy technician's job stress factors were very high. The most 
Table 4: The pharmacy technician satisfaction of management policies, Personal time and Salary and benefits.

\begin{tabular}{|c|c|c|c|c|c|c|c|c|}
\hline & Overall management policies & $\begin{array}{l}\text { Strongly } \\
\text { Agree }\end{array}$ & Agree & Neutral & Disagree & $\begin{array}{l}\text { Strongly } \\
\text { Disagree }\end{array}$ & $\begin{array}{l}\text { Rating } \\
\text { Average }\end{array}$ & $\begin{array}{l}\text { Response } \\
\text { Count }\end{array}$ \\
\hline 1 & $\begin{array}{l}\text { I am allowed a sufficient amount of freedom to decide how I do my } \\
\text { work. }\end{array}$ & 20 & 26 & 32 & 9 & 8 & 3.43 & 95 \\
\hline 2 & My workload is excessive. & 50 & 25 & 13 & 8 & 0 & 4.22 & 96 \\
\hline 3 & $\begin{array}{l}\text { Staffing is inadequate; not enough employees are hired to cover the } \\
\text { workload. }\end{array}$ & 54 & 21 & 14 & 5 & 2 & 4.25 & 96 \\
\hline 4 & $\begin{array}{l}\text { The managemen, in scheduling work hours at my place of employmen, } \\
\text { takes into account individual employee needs and preferences. }\end{array}$ & 10 & 31 & 26 & 17 & 11 & 3.13 & 95 \\
\hline 5 & I work too many weekend and holiday hours & 11 & 25 & 32 & 21 & 7 & 3.13 & 96 \\
\hline 6 & $\begin{array}{l}\text { My environmental working conditions (lighting, air conditioning, } \\
\text { heating, bathroom facilities, ventilation, noise level, etc.) are poor. }\end{array}$ & 27 & 27 & 16 & 16 & 10 & 3.47 & 96 \\
\hline & Average & & & & & & 3.61 & \\
\hline \multicolumn{9}{|c|}{ Answered question 96, Skipped question 0} \\
\hline & Personal time and related issues & $\begin{array}{l}\text { Strongly } \\
\text { Agree }\end{array}$ & Agree & Neutral & Disagree & $\begin{array}{l}\text { Strongly } \\
\text { Disagree }\end{array}$ & $\begin{array}{l}\text { Rating } \\
\text { Average }\end{array}$ & $\begin{array}{l}\text { Response } \\
\text { Count }\end{array}$ \\
\hline 1 & $\begin{array}{l}\text { I have the time to focus on continuing education and maintain my } \\
\text { professional competence }\end{array}$ & 9 & 16 & 17 & 23 & 29 & 2.50 & 94 \\
\hline 2 & I have the time to take breaks during the day. & 3 & 22 & 20 & 27 & 23 & 2.53 & 95 \\
\hline 3 & $\begin{array}{l}\text { My work has a significant contribution to the successful operation of my } \\
\text { organization. }\end{array}$ & 15 & 32 & 33 & 10 & 5 & 3.44 & 95 \\
\hline 4 & I am able to positively influence patient drug therapy. & 19 & 51 & 23 & 2 & 0 & 3.92 & 95 \\
\hline 5 & $\begin{array}{l}\text { Compared with the respect shown to other health professionals, patients } \\
\text { and customers show pharmacists an appropriate amount of respect. }\end{array}$ & 11 & 39 & 24 & 12 & 9 & 3.33 & 95 \\
\hline & Average & & & & & & 3.14 & \\
\hline \multicolumn{9}{|c|}{ Answered question 95, Skipped question 1} \\
\hline & Salary and benefits & $\begin{array}{l}\text { Strongly } \\
\text { Agree }\end{array}$ & Agree & Neutral & Disagree & $\begin{array}{l}\text { Strongly } \\
\text { Disagree }\end{array}$ & $\begin{array}{l}\text { Rating } \\
\text { Average }\end{array}$ & $\begin{array}{l}\text { Response } \\
\text { Count }\end{array}$ \\
\hline 1 & $\begin{array}{l}\text { Considering the kind of work I do and the amount of responsibility I } \\
\text { have, my pay is about right. }\end{array}$ & 4 & 14 & 16 & 34 & 28 & 2.29 & 96 \\
\hline 2 & $\begin{array}{l}\text { My salary is equivalent to the salary of persons holding similar positions } \\
\text { in other organizations. }\end{array}$ & 7 & 24 & 23 & 26 & 16 & 2.79 & 96 \\
\hline 3 & I am satisfied with my salary. & 6 & 12 & 24 & 29 & 24 & 2.44 & 96 \\
\hline & Average & & & & & & 2.51 & \\
\hline
\end{tabular}

stress factors were the number of very high prescriptions and the stress affected the Job through mental and emotional health. That is expected from the previous question with very high workload hours and may contribute to dissatisfaction, that's similar pharmacy job satisfaction. ${ }^{8}$ All previous reasons may affect pharmacist job satisfaction positively if corrected. ${ }^{13}$ Most pharmacy technicians motivations were increased the financial reward similar to the previous pharmacist study, ${ }^{16}$ and they need the flexibility of the working schedule. Besides, pharmacy technicians need more time to continue their post-graduate education and regular medical education to renew their license and improve job satisfaction and similar to previous studies. ${ }^{10,11}$ All those factors demand to raise the pharmacy technician's job satisfaction

\section{CONCLUSION}

The pharmacy technician's job satisfaction was affected with several factors, including excess workload, financial rewards and postgraduate education that did not exist. Targeting to correct the stress factors will raise pharmacy technician's job satisfaction in the Kingdom of Saudi Arabia.

\section{ACKNOWLEDGEMENT}

None.

\section{CONFLICT OF INTEREST}

The authors declare that there are no conflicts of interest. 
Table 5: The pharmacy technicians stress factors and overall job satisfactions.

\begin{tabular}{|c|c|c|c|c|c|c|c|c|}
\hline & Pharmacy stress factors & 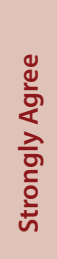 & $\begin{array}{l}\text { Фे } \\
\text { कूष }\end{array}$ & $\frac{\bar{\pi}}{2}$ & 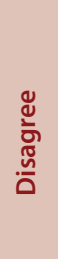 & 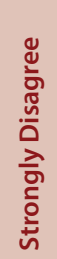 & 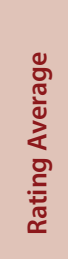 & 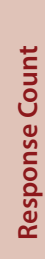 \\
\hline 1 & $\begin{array}{l}\text { The number of hours I } \\
\text { work is excessive. }\end{array}$ & 30 & 37 & 21 & 6 & 1 & 3.94 & 95 \\
\hline 2 & $\begin{array}{l}\text { The number of } \\
\text { prescriptions per day is } \\
\text { excessive. }\end{array}$ & 53 & 24 & 16 & 1 & 1 & 4.34 & 95 \\
\hline 3 & $\begin{array}{l}\text { The stress associated with } \\
\text { my job has adversely } \\
\text { affected my mental or } \\
\text { emotional health and } \\
\text { well-being. }\end{array}$ & 48 & 23 & 17 & 6 & 1 & 4.17 & 95 \\
\hline 4 & $\begin{array}{l}\text { The stress associated with } \\
\text { my job has adversely } \\
\text { affected the quality of the } \\
\text { work that I do. }\end{array}$ & 36 & 24 & 21 & 11 & 3 & 3.83 & 95 \\
\hline 5 & $\begin{array}{l}\text { The stress associated with } \\
\text { my job has adversely } \\
\text { affected my relationships } \\
\text { with friends and those } \\
\text { close to me. }\end{array}$ & 31 & 36 & 16 & 10 & 2 & 3.88 & 95 \\
\hline & Average & & & & & & 4.03 & \\
\hline \multicolumn{9}{|c|}{ Answered question 95, Skipped question 1} \\
\hline & Overall job satisfaction & 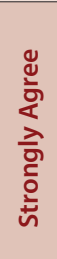 & すँ & $\begin{array}{l}\overline{\frac{\pi}{2}} \\
\frac{3}{2} \\
\frac{0}{2}\end{array}$ & 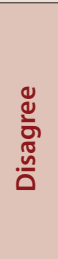 & 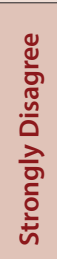 & 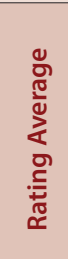 & 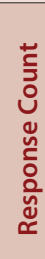 \\
\hline 1 & $\begin{array}{l}\text { I find challenge in my } \\
\text { work. }\end{array}$ & 33 & 37 & 15 & 11 & 0 & 3.96 & 96 \\
\hline 2 & $\begin{array}{l}\text { Knowing what I know } \\
\text { now, if I had to decide all } \\
\text { over again whether to go } \\
\text { into pharmacy, I would } \\
\text { choose another field. }\end{array}$ & 25 & 14 & 12 & 26 & 19 & 3.0 & 96 \\
\hline 3 & $\begin{array}{l}\text { If I were free to pursue } \\
\text { any type of career I } \\
\text { wanted, I would stay in } \\
\text { pharmacy. }\end{array}$ & 32 & 35 & 20 & 5 & 4 & 3.9 & 96 \\
\hline & Average & & & & & & 3.62 & \\
\hline
\end{tabular}

\section{ABBREVIATIONS}

KSA: Kingdom of Saudi Arabia; MOH: Ministry of Health; B.Sc. Pharm: Bachelor in pharmacy; Pharm D: Doctor of Pharmacy; CBAHI: Saudi Central Board for Accreditation of Healthcare Institutions; KPI: Key Performance Indicators.
Table 6: The pharmacy technician's motivations factors.

\begin{tabular}{|l|c|c|}
\hline $\begin{array}{l}\text { Suggest methods for motivating } \\
\text { Pharmacy technicians' practitioners }\end{array}$ & $\begin{array}{c}\text { Response } \\
\text { Count }\end{array}$ & $\begin{array}{c}\text { Response } \\
\text { Percent }\end{array}$ \\
\hline Financial rewards, salary advancements & 84 & $89.36 \%$ \\
\hline More favorable schedule & 54 & $57.45 \%$ \\
\hline Increased autonomy in the workday & 33 & $35.11 \%$ \\
\hline Flexibility in scheduling & 61 & $67.02 \%$ \\
\hline $\begin{array}{l}\text { Funds to support additional education } \\
\text { and training }\end{array}$ & 61 & $64.89 \%$ \\
\hline $\begin{array}{l}\text { Time off to achieve additional education } \\
\text { and training }\end{array}$ & 35 & $64.89 \%$ \\
\hline $\begin{array}{l}\text { Opportunity for advancement to } \\
\text { pharmacy management }\end{array}$ & 35 & $37.23 \%$ \\
\hline $\begin{array}{l}\text { Opportunity to teach/mentor pharmacy } \\
\text { students and residents }\end{array}$ & 44 & $46.81 \%$ \\
\hline Chances of promotion & 15 & $15.96 \%$ \\
\hline Other (please specify) & $94.23 \%$ \\
\hline Answered question & & \\
\hline Skipped question & & 63 \\
\hline
\end{tabular}

\section{ORCID ID}

Yousef Ahmed Alomi (D) https://orcid.org/0000-0003-1381-628X

\section{REFERENCES}

1. American Society of Health-System Pharmacists. ASHP statement on the roles of pharmacy technicians. Am J Heal Pharm. 2016;73(5):329-32.

2. Alomi YA, Alghamdi SJ, Alattyh RA. On-the-Job Training of Pharmacy Technicians at the Ministry of Health Hospitals in Saudi Arabia. Pharmacol Toxicol Biomed Reports. 2019;4(3):34-6

3. Bonenberger M, Aikins M, Akweongo P, Wyss K. The effects of health worker motivation and job satisfaction on turnover intention in Ghana: A cross-sectional study. Hum Resour Health. 2014;12(1):1-12.

4. Suleiman A. Stress and job satisfaction among pharmacists in Riyadh, Saudi Arabia. Saudi J Med Med Sci. 2015;3(3):213.

5. Belay Y. Job satisfaction among community pharmacy professionals in Mekelle city, Northern Ethiopia. Adv Med Educ Pract. 2016;7:527-31.

6. Maio V, Goldfarb NI, Hartmann CW. Pharmacists ' job satisfaction : Variation by practice setting. Pharm Ther. 2004;29(3):184-90.

7. Zahrani F, Ghamdi $M$, Ahmad R. Job satisfaction among retail pharmacists in Eastern Region of Saudi Arabia. J Pharm Res Int. 2017;19(5):1-12.

8. Slimane NSB. Motivation and job satisfaction of pharmacists in four hospitals in Saudi Arabia. J Health Manag. 2017;19(1):39-72.

9. AlKhalidi D, Wazaify M. Assessment of pharmacists' job satisfaction and job related stress in Amman. Int J Clin Pharm. 2013;35(5):821-8.

10. Coburn MJ, Gagnon JP, Eckel FM. Job Satisfaction of Hospital Pharmacy Technicians in North Carolina. Am J Heal Pharm. 1980;37(3):359-64.

11. Sanford ME, Facchinetti NJ, Broadhead RS. Observational study of job satisfaction in hospital pharmacy technicians. Am J Heal Pharm. 1984;41(12):2599-606.

12. Cortese LM, Greenberger DW, Schneider PJ, Bourret JA. Job characteristics and satisfaction of pharmacy technicians. Am J Heal Pharm. 1987;44(11):2514-8.

13. Mahoney CD, Gallina JN, Jeffrey LP. A comprehensive program to increase job satisfaction among pharmacy technicians. Hosp Pharm. 1982;17(10):547-50.

14. Alomi YA, Alghamdi SJ, Alattyh RA. Strategic Plan of General Administration of Pharmaceutical Care at Ministry of Health in Saudi Arabia 2012-2022. J Pharm Pharm Scien. 2015;1(13):1-8.

15. Alomi YA, Alghamdi SJ, Alattyh RA, Elshenawy RA. The Evaluation of Pharmacy Strategic Plan in Past 2013-2016 and Forecasting of New Vision 2030 at Ministry of Health in Saudi Arabia. J Pharm Pract Community Med. 2018;4(2):93-101.

16. Benslimane N, Khalifa M. Evaluating pharmacists' motivation and job satisfaction factors in Saudi Hospitals. Stud Health Technol Inform. 2016:226:201-4. 